\title{
Terrorism Financing: New Challenges for International Security ${ }^{1}$
}

\author{
I. Andronova, N. Gusakov, E. Zavyalova
}

Inna Andronova, Doctor of Economics, Professor, Peoples' Friendship University of Russia (RUDN University); 6 Miklukho-Maklaya Ulitsa, Moscow, 117198, Russian Federation; E-mail: aiv1207@mail.ru

Nikolay Gusakov, Doctor of Economics, Professor, Peoples' Friendship University of Russia (RUDN University); 6 Miklukho-Maklaya Ulitsa, Moscow, 117198, Russian Federation; E-mail: gusakov_np@rudn. university

Elena Zavyalova, $\mathrm{PhD}$ in Economics, Assistant Professor, Moscow State Institute of International Relations (University) of the Ministry of Foreign Affairs Russian Federation (MGIMO University); 76 Prospect Vernadskogo, Moscow, 119454, Russian Federation; E-mail: e.zavyalova@inno.mgimo.ru

\begin{abstract}
Despite efforts by the international community to curb international terrorism, it remains one of the main threats to inter- national security. A main reason for this is that international terrorism has significant financial inflows and their routes transform faster than the international countermeasures designed to stop them.

The aim of this article is to identify existing and potential financial channels. The authors analyze antiterrorist legislation to define the theoretical and legal framework for this research and draw on empirical content from the reports of international organizations, the Group of 20(G20), the International Centre for the Study of Radicalisation, and others.

This article shows that the main sources of terrorism financing include taxes paid by foreign enterprises functioning in the occupied lands, taxes paid by local populations, profits from resource and goods trade, captured treasures trade, pay- ments from non-governmental organizations, and financial fraud.

The authors discuss the role of cryptocurrencies in international terrorism financing and note that while foreign experts deny the possibility and feasibility of their usage, Russians take an opposite view. The authors conclude that the Russian arguments should be heard and carefully considered by the international community. The Russian Federation has significant experience fighting terrorism. For this reason, the authors recommend that the G20 and other international organizations pay more attention to this issue and work out international standards to counter the use of cryptocurrencies by terrorists.
\end{abstract}

Key words: terrorism financing; international counter methods to terrorism financing; national security; international security; cryptocurrencies

For citation: Andronova I., Gusakov N., Zavyalova E. Terrorism Financing: New Challenges for International Security. International Organisations Research Journal, vol. 15, no 1, pp. 120-134 (in Russian and English). DOI: 10.17323/1996-7845-2020-01-05.

\section{Introduction}

International terrorism has become a major threat to the world community. One of the most effective ways to strive against evil is to block the financing channels of terrorist organizations.

${ }^{1}$ The editorial board received the article in September 2019. 
The Group of 20 (G20) has sufficient competencies and influence to play a key role in blocking the financing of terrorism.

Since the 1960s, the world community has been actively engaged in limiting terrorist activities, including blocking possible financial flows. Over the past years, significant progress has been made in the field of traditional threats and challenges to international and national security associated with terrorist activities. However, new technologies and the rapid development of the global financial market have created opportunities for terrorism financing. The world community is facing fundamentally new sources and mechanisms for transferring money outside the control of national and international structures. Above all, this includes the use of cryptocurrencies.

The aim of this article is to examine the international legal framework for combating terrorism financing, to consider new trends in the financing of terrorism using the example of the activity of the Islamic State (ISIS) ${ }^{2}$, and to determine the specifics of new channels for terrorism financing with a focus on cryptocurrencies. It draws on the authors' examination of both traditional and new channels for terrorism financing and their analysis of data on the economic activity of the ISIS group banned in Russia, as well as material from the Financial Action Task Force (FATF) and other international organizations involved in countering the financing of terrorism.

This research identifies a significant discrepancy between the positions of western and Russian experts, not only regarding methods of combating terrorist threats, but also in their assessments of potential sources of terrorism financing. The authors present arguments in favour of the Russian position and outline recommendations that may be useful in implementing practical measures within the framework of the G20.

\section{Legal Framework for International Countermeasures to Terrorism Financing}

International terrorism and its financing are quite new threats to international and national security and they determine the agenda of many international organizations. The problem of terrorism at the interstate level was raised for the first time in the mid-twentieth century. The 1963 Convention on Offences and Certain Other Acts Committed on Board Aircraft was the first international convention against terrorism [UN, 1963]. A series of documents followed regarding security in civil aviation and hostage-taking.

Over time, the range of facilities where terrorist attacks were or could be committed has expanded, and international law has been supplemented by conventions on countering terrorism in maritime transport and on fixed platforms located on continental shelves. The arsenal of terrorist methods has also expanded [Ibid., 1988a; 1988b]. The Convention on the Marking of Plastic Explosives for the purpose of Detection was issued in 1991 should this be added to the references?, while the International Convention for the Suppression of Terrorist Bombings was issued in 1997 and the International Convention for the Suppression of Acts of Nuclear Terrorism was added in 2005 [Ibid., 1997; 2005].

Despite the adoption of a large number of conventions, statistics on the number of terrorist acts, their victims and economic damage continued to grow steadily. This led the international community to look at the problem from a different perspective. Terrorist activity is associated with high financial costs for the preparation and implementation of an attack - therefore, it is necessary to deprive terrorist organizations of financial resources.

\footnotetext{
2 The organization is banned in the Russian Federation.
} 
Work on countering terrorism financing was launched in the 1990s. In 1996, recommendations were made at the Group of 8 (G8) ministerial meeting requiring countries to: conduct continuous monitoring and control of money remittance and disclosure of banking secrecy procedures; intensify information exchange regarding the international movement of capital sent or received by organizations or groups suspected of carrying out or supporting terrorist organizations; and take measures to prevent funds transfers in respect of which there are suspicions that they are intended for terrorist organizations.

In 1998, at a meeting of the UN General Assembly, an international convention for the suppression of the financing of terrorism was adopted, which laid the foundation for legal regulation of this issue at the international level [UN, 1999]. The convention, signed by 132 states, declared terrorism financing to be a criminal offense and determined the obligations of states to prevent it. In particular, the states that signed the convention committed themselves to: fix the criminal nature of terrorism financing in their criminal legislation; take part in large-scale cooperation with other participating states; and put in force certain requirements regarding the role of financial institutions in detecting and reporting facts that indicate the financing of terrorist attacks [Ibid., 2001].

On 28 September 2001, the UN Security Council, after an avalanche of attacks against civilian targets, a series of political murders, and ultimately the events of 11 September, adopted Resolution 1373 "Threats to International Peace and Security Caused by Terrorist Acts" [Ibid.]. This resolution contained a universal and mandatory programme for a comprehensive and diverse fight against terrorism at various levels: administrative, police, civil, customs, financial and legal. For the first time, terrorism was recognized as a threat to international peace and security.

The importance of preventing and suppressing the financing of terrorist acts and terrorists in any way is highlighted in the resolution. Moreover, financing is divided into financing of terrorist attacks and financing of terrorists. As for the financing of terrorist acts, the resolution obliges member states to criminalize the deliberate provision or collection of funds, direct or indirect, that have been or will be used to commit an act of terrorism. Obligations to prevent terrorism financing include prohibiting citizens or any individuals and organizations located in the territory of the state from providing any funds, financial assets or economic resources, services, directly or indirectly, for use in the interests of persons who commit or are trying to commit terrorist acts, and facilitate or participate in their commission [Ibid.].

States were also obligated to take measures to prevent terrorist acts, to refrain from supporting terrorists and providing asylum, to assist other member states in the investigation of terrorist attacks, to intensify interstate cooperation, and to to block funds and other financial assets of persons who commit or attempt to commit terrorist attacks, or participate in the commission of terrorist acts, or assist them.

Immediately after the terrorist attacks in 2001, the FATF joined the work on countering terrorism financing, which currently includes 33 countries. In 2004, the organization developed recommendations for countries on these issues at the national level [EAG, 2004]. The recommendations worked out by the FATF are regularly updated and focus on preventing private sponsorship of terrorist groups. The document describes measures related to wire transfer and the use of alternative money transfer systems by sponsors, with special attention paid to cash transfer procedures and to recommendations on strengthening control over the work of non-profit organizations, which are often used as channels for transferring funds to terrorists' accounts [Melkumyan, 2014].

After the release of the Security Council resolution and FATF initiatives, the ministers of finance and the heads of the central banks of the G20 countries reached an agreement on freezing the accounts of terrorist organizations. In turn, the FATF encouraged countries to conduct 
a self-assessment of their implementation of international recommendations and to submit a report on the results. In this regard, the FATF has developed a self-assessment questionnaire [FATF, 2002]. According to the FAFT, 120 countries conducted a self-assessment and, based on the results, the International Monetary Fund (IMF), together with the FATF, the World Bank (WB) and several other international organizations, developed and approved the "Methodology for Assessing Compliance With Anti-Money Laundering and Combating the Financing of Terrorism Standard."

In 2017 the G20 countries adopted a roadmap for countermeasures to terrorism financing, which includes commitments to expand cooperation, to combat the financing of terrorism, and to counteract radicalization and the use of the Internet for terrorist purposes [IMF, 2002].

The issue of terrorism financing has remained at the core of the international agenda. In March 2018, G20 finance ministers and central bank governors issued a communiqué once again urging countries to use the FATF standards, which were expanded by recommendations to prevent the use of cryptocurrencies for terrorist financing [FATF, 2018].

Despite the large number of resolutions, agreements, acts and roadmaps, there have been no real reductions in the number of terrorist attacks and victims, or economic damage. The situation with countering terrorism financing is even more complicated. This is largely attributed to the difficulty of tracking financial flows and isolating those which finance terrorist activities. The basic principles of external financing may be considered using the example of ISIS.

\section{Terrorism Financing: The Example of ISIS}

ISIS is new and is currently one of the most "effective" models of terrorist organizations. Almost from the very beginning of its existence ISIS claimed the status of an Ummah, that is, a state whose members are connected to each other according to the principle of a single religion, and which is multilevel and capable of organizing a system on the network principle [Vavilov et al., 2016]. Therefore, despite the fact that there are many maps of the distribution of ISIS, it is virtually impossible to clearly determine territorial boundaries. It can be said that ISIS consists of many territorial components, reminiscent of modern Palestine.

Over the past four years, the territory controlled by ISIS has declined significantly. According to experts, while in 2014 the terrorist group controlled 100,000-150,000 square kilometres, by 2018 it controlled only 30,000. In this case, experts take into account the territories under the control of ISIS in the territory of Syria and Iraq; however, in addition to this basic geographical component, there is another, represented by a network of ISIS-affiliated groups spread around the world [Lui, 2017]. ISIS followers who are not members of any terrorist group but who carry out terrorist attacks independently or in small groups and who enjoy ISIS support, including financial, pose the same or an even greater threat. Thus, ISIS is a new entity consisting of more than 30 terrorist groups located in 14 countries from Nigeria to Indonesia which also exploits scattered, lone terrorists. Where does ISIS get funds for such large-scale activity?

One of the largest analyses in the field of ISIS financing is a report entitled "Caliphate in Decline: Assessing the Financial Situation of ISIS," produced by researchers at the International Centre for the Study of Radicalisation and Political Violence [Heißner et al., 2017]. According to these experts, the organization was financed mainly by the receipt of funds from foreign countries until 2011. However, after 2011 the organization began to develop a self-sufficiency model. And today, it can be said that ISIS has an established tax and financial system.

The main income sources of ISIS come from Islamic and non-Islamic taxes, crude oil trade, confiscations, fines, contraband antiquities trade, ransom for kidnapping, and foreign aid (see Table 1). 
Table 1. ISIS Budget 2014-16 (\$ Millions)

\begin{tabular}{|l|c|c|c|}
\hline \multicolumn{1}{|c|}{ ISIS Budget Items } & $\mathbf{2 0 1 4}$ & $\mathbf{2 0 1 5}$ & $\mathbf{2 0 1 6}$ \\
\hline Taxes & $300-400$ & $400-800$ & $200-400$ \\
\hline Oil trade & $150-450$ & $435-550$ & $200-250$ \\
\hline Kidnapping & $20-40$ & No data available & $10-30$ \\
\hline Antiques & No data available & No data available & No data available \\
\hline Robberies/Confiscations/Fines & $500-1000$ & $200-350$ & $110-190$ \\
\hline Foreign Aid & No data available & \\
\hline Total & $970-1890$ & $1035-1700$ & $520-870$ \\
\hline
\end{tabular}

Source: [Heißner et al., 2017].

As can be seen in Table 1, given that there is no data available on foreign aid, taxes are the main revenue items in the budget. Taxes paid to ISIS are divided into Islamic and non-Islamic. In Islamic tradition, there is the concept of "poor-due" (zakah). Zakah acts as a kind of property tax, amounting to $2.5 \%$, paid by any able-bodied adult Muslim whose wealth is equal to or exceeds 84.8 grams of gold. In the territory controlled by ISIS, according to experts, this tax reaches up to $10 \%$ in some areas. Given the fact that at certain points in its existence ISIS controlled territories with a population of 10 million people, the total collection of this tax is quite substantial in general.

Another type of Islamic tax collected by ISIS is a tax on agricultural products or a trade tax in the amount of one tenth of the good's price, and a so-called tax on adherents of different faiths. The latter serves essentially as a ransom ensuring the security of non-Muslim people. In addition, non-Muslims are required to pay a tax for the use of territory conquered by Muslims.

ISIS also collects non-Islamic taxes. The most significant is the payroll tax, which varies from $10 \%$ to $50 \%$ depending on the position held. Moreover, ISIS levies customs duties on vehicles entering territory controlled by the organization.

ISIS residents are required to pay up to $\$ 2$ per month for water, electricity and telephone communications for each item [CAT, 2017]. Given the number of people living in ISIS-controlled territory, the total amount of funds raised can be several million dollars.

The territories occupied by ISIS are rich in deposits of phosphates, sulphur and inputs required to make cement. Apart from mining capacities, ISIS bogarted mineral water and soft drinks factories, furniture factories, mobile operators, and cement and chemical plants. The ISIL ministry of resources manages all profits at its discretion. ISIS also controls a significant amount of the most fertile land in Iraq and Syria.

The most important question is which companies operate in ISIS territory. It should be noted that for security reasons, most foreign enterprises have scaled down their operations, although there are some that remain. The most striking example is the French cement business, Lafarge [Le Monde, 2016]. The company's Syrian plant, Lafarage Cement Syria, was located in northern Syria. It is one of the few companies that stayed and continued to work in a region controlled by Syrian rebels. As a result, it had to pay various fees for the workers' safe access to the plant. Payments were made on a monthly basis and increased constantly. In July 2012 the first payment was $\$ 57,000$ but by November 2013 it had reached \$160,000 [Le Monde, 2018]. Moreover, the company paid taxes regularly. For example, a $10 \%$ tax on the cost of manufactured products, and special "transport" taxes, which varied depending on the tonnage of the 
cargo - according to estimates, the total amount could reach \$5.3 million [Le Monde, 2018]. In addition to direct payments, the company contributed to the increase in ISIS' financial capabilities by purchasing raw materials. According to experts, Lafarage could spend about $\$ 2.5$ million on raw materials [Ibid.]. The plant ceased operations in Syria on 19 September 2014. In the summer of 2018, a trial took place during which it was established that over the years of its operation the plant had transferred a total of $€ 13$ million to ISIS.

Another budget feeder for the terrorist organization is income from the sale of oil. According to experts, its annual income from this source is about $\$ 450$ million [Vesti, 2017]. It is extremely difficult to identify buyers of ISIS oil because of the creation of a well-organized and extensive network of partners and customers. However, the sale of ISIS' oil to the world community was significantly reduced because oil transportation is clearly visible and is a convenient target for airstrikes.

The situation is more complicated with the blocking of sources of terrorism financing such as donations from other terrorist groups and organizations, foreign funds, non-profit organizations and individuals - which are not reflected in the ISIS budget in any way. The amount of aid from the latter accounts for the largest percentage of the total amount of this type of infusion. Direct funds, according to experts, come from individuals, business people and religious leaders, mainly from the Gulf countries [CAT, 2015]. Moreover, both important business people and ordinary citizens can act as private donors and the amounts of their transfers range from $\$ 50$ to hundreds of thousands or more. According to experts, a large role is played by the collection of donations in cultural centres and prayer halls made by ISIS sympathizers in western countries, as well as fundraising through social networks. Saudi Arabia and Qatar are also accused of financing ISIS [Laurent, 2015].

The world community is seriously concerned about the tendency to use non-profit organizations to channel funds to finance terrorist activities. It is extremely difficult to prove the involvement of such organizations since the funds allocated for financing terrorists are difficult to separate from other funds managed by the same non-profit organization. In fact, the only difference between a legal and illegal donation to or on behalf of a non-profit organization is the intention of the donor. The water is muddied by the fact that there have been a number of cases where non-profit organizations had no idea that they were being used for illegal purposes [IMF, 2003].

Another poorly controlled source of terrorist financing, according to the FATF, is fraud, for example, tax refunds, fictitious export schemes, various cashing schemes, as well as the work of bank branches and small- and medium-sized money transfer companies - some of which are involved in regional smuggling networks that existed and successfully functioned long before the emergence of ISIS, and whose activity is almost impossible to trace.

Ransom for kidnapping is one of the least significant among the presented ISIS funding sources. Nevertheless, ISIS was able to earn between \$20-40 million through such activities in 2014, and between \$10-30 million in 2016.

The sale of antiquities is another important ISIS budget item. ISIL controlled 2,500 archaeological sites in Iraq and 4,500 in Syria in 2015 [Osborne, 2015]. In addition, people were ready to pay money for the preservation of other relics of the city after the bombings of the Temple of Baalshamin or the Temple of Bel in captured Palmyra were published [Alekhina, 2015]. In general, research shows that ISIS makes money on historical artefacts in three ways: sale of excavation rights; sale of found valuables in the international market; and sale of rights to export art objects from controlled territories [Rose-Greenland, 2016].

In the first years of the caliphate, this particular item was the most profitable and brought ISIS between $\$ 500$ million to $\$ 1$ billion. Gradually, the share of this income item has declined. The estimated amounts decreased to \$200 million in 2015, and to \$110-\$190 million in 2016 . 
However, the profit made by the organization under this item remains, even according to estimates, very substantial. Evidently, in order to replenish its budget, ISIS will continue to capture new territories and objects of historic importance.

Another source of income is fines for violation of Shariah rules, including smoking or wearing clothes that do not conform with the requirements of the religious norms. The amount of the fine varies depending on the severity of the violation, but on average it starts at $\$ 100$ and ends at \$500 [Bekkin, 2017].

While these sources of financing are known to the world community and have been studied, the development of information and financial technologies has made possible another source of financing in the form of cryptocurrencies.

\section{New Sources of Terrorism Financing}

One of the most discussed issues today is the possibility of using cryptocurrencies for purposes prohibited by law. There is no unequivocal opinion among experts. However, an interesting pattern is clearly visible: Russian experts talk about serious danger arising from technological features more often. The director of the Russian Federal Security Service, Alexander Bortnikov, has repeatedly claimed that there is "a large-scale use of encrypted Internet communications, electronic banking and cryptocurrencies, remote terrorist management and financing schemes" [ForkLog, 2018].

On the other hand, most western experts tend to underestimate these risks. According to a statement by Yaya Fanusie, senior member of the Democracy Defense Fund, Forbes author Ted Knutson, and U.S. defence experts, cryptocurrencies are not suitable for financing terrorism [Fanusie, 2018].

The potential risks, as well as the degree of their probability should be assessed. It is reasonable to start with an optimistic position. Terrorists still prefer conventional money and there are reasons for this. First, terrorists do not "work" predominantly in countries with a highly developed technological sector, which complicates operations with cryptocurrencies. Second, the application of laws on customer verification and the fight against money laundering makes it even more difficult for terrorists to access cryptocurrencies. Moreover, government departments have begun tracking popular blockchain transactions. It turns out that the use of physical money is more anonymous and more difficult to track. In addition, some terrorist networks have their own payment systems. All of this makes the extensive use of cryptocurrency to finance terrorism inappropriate. As a consequence, most terrorists still use the traditional hawala payment system, as well as other traditional financial channels [Goldman et al., 2017].

Another argument made by western colleagues is that terrorists do not yet have the necessary skills to use cryptocurrency more frequently and more effectively. It is believed that the use of cryptocurrency requires special skills in the field of information security. Moreover, the cryptocurrency exchange rate is volatile and this makes it less attractive for both ordinary users and terrorists.

This all seems comforting, but there is a downside to these arguments. The most important advantage, and at the same time, the main disadvantage of any cryptocurrency is the fact that it is almost impossible to track the movement of funds using cryptocurrencies. Most cryptocurrencies are anonymous and do not require identification, as when using a bank account. Therefore, it is an ideal means of payment for the purchase of arms and other illegal goods.

Global availability is another attractive point. The system solves the problem of transferring money from anywhere at any time for any amount. Users can perform transactions through other countries and can erase traces through the use of different exchange markets and bureaus 
from different countries. Further, such operations are much faster than traditional transactions, so the likelihood that it will be intercepted and blocked is much lower.

It seems that the widespread opinion about the low awareness and professionalism of supporters of banned organizations does not correspond to reality. But even assuming this option, one must understand that most cryptocurrencies are quite simple to use due to the easy interface and understandable actions.

But the most attractive feature encouraging the use of cryptocurrencies for illegal purposes is the lack of a clear legal framework for cryptocurrencies around the world. In some countries they are completely free and in others they are actively used to collect donations, which makes it possible to attract large numbers of people.

The authorized bodies, both at the national and international levels, face the serious challenge of developing measures to control illegal traffic in the digital economy. One of the most significant challenges for the international financial system is the development of distributed registry technologies, which are the "heart" of all cryptocurrencies. The problem of cryptocurrencies from the perspective of state control is their anonymity and the inability to determine the direction of cash flow which complicates the tracking of terrorism financing. In Russia, for example, the development and mass use of cryptocurrencies will jeopardize the entire concept of Federal Law No 115 "On Counteracting the Legalization (Laundering) of Criminally Obtained Incomes and the Financing of Terrorism," which is simply not adapted to the realities of cryptocurrency asset circulation.

Another challenge to national and international security is the development of shadow marketplaces that maximally anonymize actions and transactions in the market. Use of the Tor anonymizing browser is not a difficult process even for an ordinary user, and on darknet sites users can obtain a number of illegal services: drugs, corporate and state secrets, weapons (including explosives and chemical weapons), illegal pornographic materials, carding services (stealing money from credit and debit bank cards or terminals), installation of virus software and hacking websites, murder for hire, and chemical substances. According to experts, the turnover on Hydra, one of the most popular darknet platforms, is on average $\$ 500,000$ per day [Pichkov, Ulanov, 2017]. Moreover, payment exclusively made with cryptocurrency allows people to hide cash flows, as well as the beneficiaries and agents of transactions.

What can be done? No matter how sad it may seem, the only way out is to strengthen state and international supervisory control in the field of activities on the Internet and the handling of cryptocurrency assets. Increased implementation of identification and authentication mechanisms for performing any activity on the Internet is seen as rational, and will allow users to be identified from their digital footprint. It will also then be possible, using large data analysis mechanisms, to form a digital user profile which can be used for predictive analytics to deliberately suppress potentially criminal acts. It is assumed that such mechanisms will be developed simultaneously with the maturation of the above-mentioned problems. It is important for states to start developing and investing in these mechanisms in order to be prepared for the evolution of the shadow digital economy market.

\section{Conclusions and Recommendations}

Having analyzed the system of terrorism financing using the example of one of the newest and most influential terrorist organizations, and having identified new potential sources of financing for international terrorism, it is clear that this topic should remain on the G20's agenda.

This article identified several mechanisms for terrorism financing: taxes from foreign enterprises that have not ceased their activity in occupied territories; taxes on residents of the 
occupied territory; income from the sale of natural resources and manufactured products in the occupied territory; revenues from the sale of captured historic assets; and income received through non-governmental organizations, as well as through financial fraud.

The discussion that has emerged in the international expert community regarding the possibility of using cryptocurrencies in terrorism financing was also examined. It should be highlighted that due to the novelty and complexity of the issue, a comprehensive assessment of the possibility of using cryptocurrencies in the financing of terrorism, and in particular of specific schemes for this use, could not be provided as this would require a review of the situation for each existing cryptocurrency which, so far, exist outside the international legal field. Therefore, it recommended that the G20 together with the FATF should continue monitoring this topic and should develop and implement international standards in the field of countering the use of cryptocurrency in terrorism financing. This research, ultimately, can contribute to the strengthening of international cooperation in the fight against international terrorism and increase the status of the G20 in the eyes of the world community.

\section{References}

Alekhina Y. (2015) 13 pamyatnikov, kotorye razrushili terroristy IGI [13 Monuments Destroyed by ISIS Terrorists]. Komsomol'skaya Pravda, 10 May. Available at: https://www.kp.ru/daily/26441.5/3312201/ (accessed 28 October 2018). (in Russian)

Bekkin R.I. (2017) Islamskaya ehkonomika v "Islamskom gosudarstve"? [Islamic Economy in the "Islamic State"?]. Vestnik MGIMO-Universiteta [Bulletin of MGIMO-University], vol. 6, no 57, pp. 132-42. Available at: https://doi.org/10.24833/2071-8160-2017-6-57-132-142. (in Russian)

Center for the Analysis of Terrorism (CAT) (2015). ISIS Financing 2015. Available at: http://cat-int.org/wpcontent/uploads/2017/03/ISIS-Financing-2015-Report.pdf (accessed 27 October 2018).

Eurasian Group on Combating Money Laundering and Financing of Terrorism (EAG) (2004). Special'nye Rekomendacii po predotvrashcheniyu finansirovaniya terrorizma goda [Special Recommendations for Preventing the Financing of Terrorism]. Available at: https://eurasiangroup.org/files/documents/9_special_recomendations.pdf (accessed 29 October 2018). (in Russian)

Fanusie Y.J. (2018) Survey of Terrorists Groups and Their Means of Financing. Foundation for Defence of Democracies. Available at: https://docs.house.gov/meetings/BA/BA01/20180907/108661/HHRG-115-BA01Wstate-FanusieY-20180907.pdf (accessed 1 March 2020).

Financial Action Task Force (FATF) (2002). Special Recommendations on Terrorist Financing. Available at: http://www.fatf-gafi.org/TerFinance_en.htm (accessed 1 March 2020).

Financial Action Task Force (FATF) (2018). Annual Report 2017-2018. Available at: http://www.cbr.ru/Content/Document/File/48581/FATF-annual-report-2017-2018.pdf (accessed 27 October 2018).

ForkLog (2018). FSB Rossii: kriptovalyuty aktivno ispol'zuyutsya terroristami [FSB of Russia: Cryptocurrencies Are Actively Used by Terrorists], 4 May. Available at: https:/forklog.com/fsb-rossii-kriptovalyuty-aktivno-ispolzuyutsya-terroristami/ (accessed 28 October 2018). (in Russian)

Goldman Z.K., Maruyama E., Rosenberg E., Saravalle E., Soloman-Strauss J. (2017) Terrorist Use of Virtual Currencies: Report / Center for a New American Security. Available at: https://www.cnas.org/publications/ reports/terrorist-use-of-virtual-currencies (accessed 25 October 2018).

Heißner S., Neumann P.R., Holland-McCowan J., Basra R. (2017) Caliphate in Decline: An Estimate of Islamic State's Financial Fortunes. The International Centre for the Study of Radicalisation and Political Violence (ICSR). Available at: http://icsr.info/wp-content/uploads/2017/02/ICSR-Report-Caliphate-in-Decline-An-Estimate-of-Islamic-States-Financial-Fortunes.pdf (accessed 26 October 2018).

International Monetary Fund (IMF) (2002). Report on the Outcome of the FATF Plenary Meeting and Proposal for the Endorsement of the Methodology for Assessing Compliance with Anti-Money Laundering and 
Combating the Financing of Terrorism Standards, Annex II. Available at: http://www.imf.org/external/np/ mae/aml/2002/eng/110802.pdf (accessed 26 October 2018).

International Monetary Fund (IMF) (2003). Bor'ba s finansirovaniem terrorizma. Rukovodstvo po podgotovke zakonodatel'nyh aktov [The Fight Against the Financing of Terrorism: Legislative Guide]. Available at: https://www.imf.org/external/pubs/ft/SFTH/rus/SFTHr.pdf\#3 (accessed 26 October 2018). (in Russian)

Laurent S. (2015) L'Etat Islamique. Paris: Editions du Seuil.

Le Monde (2016). Comment le cimentier Lafarge a travaille avec l'Etat islamique en Syrie, 21 June. Available at: http://abonnes.lemonde.fr/proche-orient/article/2016/06/21/comment-le-cimentier-lafarge-a-travailleavec-1-etat-islamique-en-syrie_4955039_3218.html (accessed 28 October 2018).

Le Monde (2018). Financement du terrorisme par Lafarge: mode d'emploi, 30 April. Available at: http:// abonnes.lemonde.fr/international/article/2018/04/30/financement-du-terrorisme-par-lafarge-mode-d-emploi_5292420_3210.html?xtmc=lafarge\&xtcr=1 (accessed 28 October 2018).

Lui K. (2017) Indonesia's Military Chief Says ISIS Cells Are in 'Almost Every Province' of the Country. Time, 13 June. Available at: http://time.com/4816005/indonesia-islamic-state-isis/ (accessed 26 October 2018).

Melkumyan K.S. (2014) FATF v protivodejstvii finansirovaniyu terrorizma (specifika podhoda) [FATF in Countering the Financing of Terrorism (Specifics of the Approach)]. Vestnik MGIMO-Universiteta [Bulletin of MGIMO-University], vol. 1, no 34, pp. 88-96. Available at: https://vestnik.mgimo.ru/jour/article/view/20718160-2014-1-34-88-96/13. (in Russian)

Osborne A. (2015) Islamic State Looting Syrian, Iraqi Sites on Industrial Scale - UNESCO. Reuters, 2 July. Available at: https://uk.reuters.com/article/uk-mideast-crisis-unesco/islamic-state-looting-syrian-iraqi-siteson-industrial-scale-unesco-idUKKCN0PC1OS20150702 (accessed 27 October 2018).

Pichkov O.B., Ulanov A.A. (2017) Riski i nesovershenstva razvitiya cifrovoj ehkonomiki na sovremennom ehtape [Risks and Imperfections of Digital Economy Development at the Present Stage]. Strahovoe delo [Insurance Business], no 11, pp. 3-8. (in Russian)

RBK (2015). Ehrdogan zayavil o nedopustimosti obvinenij v priobretenii nefti u IGIL [Erdogan Says that Accusations of Buying Oil From ISIS Are Unacceptable], 2 December. Available at: https://www.rbc.ru/politics/ 02/12/2015/565f04bf9a7947ad72fd739e (accessed 21 October 2018). (in Russian)

Rose-Greenland F. (2016) How Much Money Has ISIS Made Selling Antiquities? More Than Enough to Fund Its Attacks. The Washington Post, 3 June. Available at: https://www.washingtonpost.com/posteverything/ wp/2016/06/03/how-much-money-has-isis-made-selling-antiquities-more-than-enough-to-fund-itsattacks/ (accessed 21 October 2018).

United Nations (UN) (1963). Konvenciya o prestupleniyah i nekotoryh drugih aktah, sovershaemyh na bortu vozdushnyh sudov 1963 [The Convention on Offences and Certain Other Acts Committed on Board Aircraft 1963]. Available at: http://www.un.org/ru/documents/decl_conv/conventions/crimes_aboard.shtml (accessed 20 October 2018). (in Russian)

United Nations (UN) (1988). Konvenciya o bor'be s nezakonnymi aktami, napravlennymi protiv bezopasnosti morskogo sudohodstva [Convention for the Suppression of Unlawful Acts Against the Safety of Maritime Navigation]. Available at: http://www.un.org/ru/documents/decl_conv/conventions/maritme.shtml (accessed

20 October 2018). (in Russian)

United Nations (UN) (1988). Protokol o bor'be s nezakonnymi aktami, napravlennymi protiv bezopasnosti stacionarnyh platform, raspolozhennyh na kontinental'nom shel'fe [Protocol for the Suppression of Unlawful Acts Against the Safety of Fixed Platforms Located on the Continental Shelf]. Available at: http://www.un.org/ ru/documents/decl_conv/conventions/shelf_security.shtml (accessed 21 October 2018). (in Russian)

United Nations (UN) (1997). Mezhdunarodnaya konvenciya o bor'be s bombovym terrorizmom [International Convention for the Suppression of Terrorist Bombings]. Available at: http://www.un.org/ru/documents/ decl_conv/conventions/bombing.shtml (accessed 21 October 2018). (in Russian)

United Nations (UN) (1999). Mezhdunarodnaya konvenciya o bor'be s finansirovaniem terrorizma [Convention for the Suppression of the Financing of Terrorism]. Available at: http://www.un.org/ru/documents/ decl_conv/conventions/terfin.shtml (accessed 21 October 2018). (in Russian) 
United Nations (UN) (2001). Sovet Bezopasnosti Rezolyuciya S/RES/1373 (2001) [Security Council Resolution S/RES/1373 (2001)]. Available at: https://www.unodc.org/pdf/crime/terrorism/res_1373_russian.pdf (accessed 1 March 2020). (in Russian)

United Nations (UN) (2005). Mezhdunarodnaya konvenciya o bor'be s aktami yadernogo terrorizma [International Convention for the Suppression of Acts of Nuclear Terrorism]. Available at: http://www.un.org/ru/ documents/decl_conv/conventions/nucl_ter.shtml (accessed 21 October 2018). (in Russian)

Vavilov A.I., Zinin Yu.N., Kazancev AA., Krylov AV., Orlov AA., Fedorchenko AV., Chechevishnikov AL., Yarlykapov AA. (2016) "Islamskoe Gosudarstvo:" fenomen, ehvolyuciya, perspektivy ["Islamic State:" The Phenomenon, Evolution, Prospects]: Analytical Reports (Institute of International Studies). Moscow State Institute of International Relations (U) of the MFA. Moscow: MGIMO University, iss. 1 (45), pp. 5-44. Available at: https://cyberleninka.ru/article/n/2016-10-009-a-vavilov-yu-zinin-a-kazantsev-a-krylov-a-orlov-afedorchenko-a-chechevishnikov-a-yarlykapov-islamic-state-phenomenon-evolution/viewer. (in Russian)

Vesti (2017). Dohody IGIL ot prodazhi nefti ruhnuli na 90\% [ISIS Revenue From Oil Sales Collapsed 90\%]. Available at: https://www.vestifinance.ru/articles/91860 (accessed 28 October 2018). (in Russian) 